ACTA AGROBOTANICA

Vol. 62 (2): 207-212

2009

\title{
THE ALLELOPATHIC EFFECT OF Taraxacum officinale F.G. Wigg ON THE SEEDS GERMINATION AND INITIAL GROWTH OF Lolium westerwoldicum R.Br.
}

\author{
Jolanta Jankowska, Grażyna Anna Ciepiela, Jacek Sosnowski, \\ Roman Kolczarek, Kazimierz Jankowski
}

\author{
University of Podlasie, Institute of Agronomy \\ 08-110 Siedlce, B. Prusa 14, Poland \\ e-mail: laki@ap.siedlce.pl
}

Received: 3.06 .2008

\section{Abstract}

The common dandelion (Taraxacum officinale F.H. Wigg) is a perennial plant often found in large concentrations in the sward of natural meadows. This species expands quickly, displacing other species. In literature there is a lack of data relating to the effect of common dandelion on plants growing in its vicinity. It is also not known why this species creates large clusters. Perhaps it competes with different plants through the allelopathic effect.

Hence, the aim of this study was to determine the influence of water extracts from leaves and roots of common dandelion (Taraxacum officinale) as well as soil extracts from the root layer of this species on seed germination and the initial growth of Lolium westerwoldicum R.Br. The investigated material comprised leaves and roots of Taraxacum officinale. The germination biotest most often used in experiments was applied. The seeds germination energy of westerwolds ryegrass was most inhibited by plant extracts prepared from roots and leaves of Taraxacum officinale. The germination ability of seeds of Lolium westerwoldicum was the highest in the treatments in which soil extracts were applied; however, the value of this feature was limited to a larger extent by the plant extracts from leaves of Taraxacum officinale than from roots.

Higher concentrations of both soil and plant solutions had an inhibitory effect both on root growth and the growth of the leaf sheath and leaves of westerwolds ryegrass. The results of the tested parameters can confirm the allelopathic effect of Taraxacum officinale on germination and initial growth of Lolium westerwoldicum, and especially that of extracts prepared from leaves.

Key words: Taraxacum officinale, allelopathy, Lolium westerwoldicum, seeds germination, initial growth

\section{INTRODUCTION}

A phenomenon commonly observed on permanent meadows and pastures is the disappearance of some species and the invasion of others. This of- ten leads to the simplification of the composition of species, reduces the yield, sustainability value and persistence of communities or even results in their degradation (Emeterio et al. 2003; Harkot and L i p i ń s k a , 2007). With the knowledge of the causes of adverse changes in the botanical composition of grassland sward, attention has been lately paid to the interaction of plants, as a result of which some species push out the others from sward. This happens because plants compete with each other for environment resources (S o u z a et al. 1997; B o u r d o t et al. 1996). For many years, however, the impact of one plant on another one was considered only from the standpoint of competition, failing to recognize the action of specific substances released from wild plants (D u e r, 1988). The allelopathic effect is a particular case of plant competition for living space.

In multispecies plant communities of grassland, plants of different species and different organs of these plants are a source of allelopathic substances. They can be in the above-ground parts (vegetative and generative) and underground parts, both live and dead, which are located on the surface of the soil, but also in the soil (B e r t i n et al. 2003). Due to the evolution of plants, various chemical compounds of one plant, which have allelopathic properties, may be an inhibitory or stimulating effect on another one ( $\mathrm{Hoffm}$ a $\mathrm{n}$ and $\mathrm{Z}$ as t a w n y ,2000). Many allelopathic compounds in the above-ground parts (e.g. leaves, stems, flowers) are dissolved in water, so they can be eluted by rain, mist or dew drops (B e y s c h la g et al. 1996; P u n t a m and T a n g , 1986). Plant residues may also be an important source of allelocompounds. According to $\mathrm{Hark} \mathrm{ot}$ and Li pińska (1997), the number of released allelopathic substances is however determined by their 
level, which is conditioned genetically in plants. The chemical effect of this process is that the donor plant emits into the environment chemicals which affect positively or negatively the development of neighboring organisms - acceptors (Le s z c z y ńska and Grabińs si , 2004).

Among meadow plants, high allelopathic activity is shown by species such as Elymus repens, Festuca rubra and Festuca arundinacea Schleb., Bromus inermis and Bromus hordeaceus, Lotus corniculatus L., Trifolium repens L., Trifolium pretense, Trifolium hybridum L, and Plantago lanceolata L., Achillea millefolium L, Hieracium pilosella L. (H a r k o t et al. 1993, Souza et al. 1997, Takah as hi et al. 1988).

In natural meadow sward, Taraxacum officinale is a plant often occurring in many communities. This perennial grows rapidly and crowds out other plants growing nearby. The determination of the allelopathic potential of this dicotyledonous plant can be used in farming practice.

Therefore, the aim of this study was to determine of the possible effect of water extracts from leaves and roots of Taraxacum officinale and soil extracts from the root layer of this perennial plant on the seeds germination and initial growth of Lolium westerwoldicum.

\section{MATERIALS AND METHODS}

The study included a laboratory experiment in which varied concentrations of water and soil solutions as well as plant extracts derived from (Taraxacum officinale F.H. Wigg) were used. The research material was collected in late autumn from natural meadow communities. The obtained plant material (leaves, roots) and soil were dried at room temperature, then ground. Then it was used to make water extracts. For this purpose, samples of leaves and roots with a weight of 25 , 50 and 75 grams and samples of soil with a weight of 500, 1000 and 1500 grams were prepared. The obtained material, after placing it in Erlenmeyer flasks and filling the flasks with cold distilled water, was left for 24 hours at room temperature. $500 \mathrm{ml}$ of water was used for the plant material, and $1000 \mathrm{ml}$ for the soil material. The obtained extract was filtered through filter paper, and then it was used to carry out the biotests. The most frequently used seed germination test was applied. The test plant in the experiment was westerwolds ryegrass (Lolium westerwoldicum R.Br.). Seeds of the test plants (25 units) in three replications were placed on Petri dishes with a diameter of $15 \mathrm{~cm}$, on two layers of filter paper. During the experiment, the seeds were irrigated at three-day intervals with $5 \mathrm{ml}$ of each of the three plant or soil extracts. The control was irrigated with distilled water. On the other day, all the treatments were watered only with distilled water.
In this experiment, the following system was used:

1. Control (distilled water)

2. Water extracts from leaves - $(25,50$ and $75 \mathrm{~g}$ of leaves);

3. Water extracts from roots $-(25,50$ and $75 \mathrm{~g}$ of roots);

4. Water extracts from soil $-(500,1000$ and $1500 \mathrm{~g}$ of soil);

The seed germination was carried out in daylight at room temperature. The period for which germination energy and germination capacity of Lolium westerwodicum were calculated was adopted from the International Seed Testing Rules (2002). After a period of 5 days from the date of experiment establishment, the energy of germination was examined, and after 14 days from this date germination capacity was determined. Three measurements were also made of seedling height at three-day intervals as well as one measurement of the length of embryonic roots. Measurements of leaf blade length and leaf sheath were made the next day after the estimation of germination, while root length was measured during the last measurement.

The obtained results were analyzed for variance of a one-factor experiment. The significance of differences was assessed by Tukey's test at a level of $\alpha \leq$ 0.05 .

\section{RESULTS AND DISCUSSION}

\section{Energy germination}

Energy germination of Lolium westerwoldicum in all the combinations of Taraxacum officinale extracts was lower than in the control treatment (Tab. 1). Similar results were obtained by $\mathrm{Hark}$ ot et al. (1993, 1997). The extracts from the leaves of Taraxacum officinale had the highest impact on the studied feature of the test plant. In this case, energy germination was most inhibited. The extracts from the roots showed a weaker effect on the energy, whereas in the case of the soil extract the effect was most similar to the control conditions. Germination energy under the influence of the soil extracts was weaker, about $36 \%$ on the average, than the control treatment. As opposed to the root extracts, where the decrease of this energy was equal to $72 \%$, and the extracts from the leaves resulted in a decrease of more than $97 \%$. The negative impact of substances contained in water extracts obtained from leaves was observed in the studies by B ertin (2003).

In their studies, W a rdle et al. (1996) also demonstrated the inhibitory effects of water extracts from leaves of Festuca arundinacea on seed germination of Lotus corniculatus and Trifolium pratense. 
Table 1

Germination energy of Lolium westerwoldicum depending on the concentration of water extracts from soil and plants.

\begin{tabular}{lccccccc}
\hline \multirow{2}{*}{ Extract from } & \multicolumn{8}{c}{ The mass of the sample (in g) } \\
\cline { 2 - 9 } & 0 & 500 & 1000 & 1500 & 25 & 50 & 75 \\
\hline Soil & $52 \mathrm{a}$ & $36 \mathrm{~b}$ & $36 \mathrm{~b}$ & $28 \mathrm{c}$ & - & - & - \\
\hline Roots & $52 \mathrm{a}$ & - & - & - & $24 \mathrm{~b}$ & $20 \mathrm{c}$ & $0 \mathrm{~d}$ \\
\hline Leaves & $52 \mathrm{a}$ & - & - & - & $4 \mathrm{~b}$ & $0 \mathrm{c}$ & $0 \mathrm{c}$ \\
\hline
\end{tabular}

- The means in lines marked with the same letters do not differ significantly

Similar results were obtained by Lipińska and Harkot (2005) in their studies on Poa pratensis; greater allelopathic activity was shown by substances released from decomposing leaves than from decomposing roots of this species. In addition, it can be mentioned that both soil and plant extracts significantly decreased the germination energy of seeds of Lolium westerwoldicum.

\section{Germination capacity}

Germination capacity is another important parameter in assessing the biological species of grasses. As in the case of germination energy, all the tested extracts also affected significantly the germination capacity of Lolium westerwoldicum (Tab. 2). In the control treatments, the germination capacity was very high, reaching the value of $96 \%$. The highest capacity, while being close to the control treatment, was shown by the treatments in which extracts from the soil were used. In this case, at two lower concentrations, this feature reached the value of $88 \%$, and at the lowest concentration $80 \%$. Lower germination capacity of Lolium westerwoldicum seeds was observed after the application of root extracts. Depending on the increased concentration applied, the value of the trait was reduced from $16 \%$ to $8 \%$.

Seeds of Lolium westerwoldicum clearly showed the lowest germination capacity, when it was watered with the extracts from leaves of Taraxacum officinale. In those treatments, along with increased concentrations, the germination capacity decreased from $12 \%$ to its disappearance at the highest concentration. Both the energy germination and germination capacity in all the combinations of the extracts showed lower values than in the control conditions.

J o d e $\nmid \mathrm{k}$ a et al. (2003) obtained similar results in their studies concerning the allelopathic effect of Hieracium pilosella on the initial development of $\mathrm{Lo}$ -

Table 2

The germination capacity of Lolium westerwoldicum depending on the concentration of water extracts from soil and plants.

\begin{tabular}{lccccccc}
\hline \multirow{2}{*}{ Extract from } & \multicolumn{7}{c}{ The mass of the sample (in g) } \\
\cline { 2 - 9 } & 0 & 500 & 1000 & 1500 & 25 & 50 & 75 \\
\hline Soil & $96 \mathrm{a}$ & $88 \mathrm{~b}$ & $88 \mathrm{~b}$ & $80 \mathrm{c}$ & - & - & - \\
\hline Roots & $96 \mathrm{a}$ & - & - & - & $16 \mathrm{~b}$ & $12 \mathrm{c}$ & $8 \mathrm{~d}$ \\
\hline Leaves & $96 \mathrm{a}$ & - & - & - & $12 \mathrm{~b}$ & $8 \mathrm{c}$ & $0 \mathrm{~d}$ \\
\hline
\end{tabular}

- The means in lines marked with the same letters do not differ significantly

lium perenne and Festuca rubra. In this experiment, both tested parameters also reached lower values than in the control treatments.

\section{Biometric parameters of Lolium westerwoldicum seedlings Leaf sheath length}

In the experiment, measurements were carried out of the length of leaf sheath, leaf blade and embryonic roots of Lolium westerwoldicum.

Generally, plant extracts (from leaves and roots) significantly affected leaf sheath length, but no such relationship was observed in the case of soil extracts. Un- der the influence of the latter extracts, leaf sheath showed the same length as in the control conditions (Tab. 3). At two lower concentrations of the soil extract, it reached the same length as in the control treatment $(17 \mathrm{~mm})$, and at the highest concentration it was only $2 \mathrm{~mm}$ shorter. When the tested plants were watered with the extracts from the roots of Taraxacum officinale, the length of sheaths did not change in relation to the control treatment only under the influence of the lowest concentration, and inhibitory effects of higher concentrations were observed.

However, the extracts from Taraxacum officinale leaves showed the greatest allelopathic effect on the tested feature. If the lowest concentration of this 
Table 3

Length of leaf sheath of Lolium westerwoldicum depending on the concentration of water extracts from soil and plants.

\begin{tabular}{lccccccc}
\hline \multirow{2}{*}{ Extract from } & \multicolumn{7}{c}{ The mass of the sample (in $)$} \\
\cline { 2 - 9 } & 0 & 500 & 1000 & 1500 & 25 & 50 & 75 \\
\hline Soil & $17 \mathrm{a}$ & $17 \mathrm{a}$ & $17 \mathrm{a}$ & $15 \mathrm{a}$ & - & - & - \\
\hline Roots & $17 \mathrm{a}$ & - & - & - & $17 \mathrm{a}$ & $9 \mathrm{~b}$ & $6 \mathrm{c}$ \\
\hline Leaves & $17 \mathrm{a}$ & - & - & - & $11 \mathrm{~b}$ & $3 \mathrm{c}$ & $2 \mathrm{c}$ \\
\hline
\end{tabular}

- The means in lines marked with the same letters do not differ significantly

extract is used, sheaths are $6 \mathrm{~mm}$ shorter compared to the control. In the treatments in which higher concentrations of this extract were used, the leaf sheaths were shorter and they were, respectively, $3 \mathrm{~mm}$ and $2 \mathrm{~mm}$. Similarly, Hark ot et al. (2000) showed in their study that substances released from decomposing leaves of Lolium perenne had a negative impact on the length of leaf sheaths.

\section{Leaf blade length}

Generally, all the extracts used in this experiment significantly affected the length of leaf blades of Lolium westerwoldicum. In this experiment, the longest leaf blades in the tested plants developed in the treatments watered with the soil extracts but they proved to be the most similar to the value reached in the control treatment (Tab. 4).

Table 4

Length of leaf blades of Lolium westerwoldicum depending on the concentration of water extracts from soil and plants.

\begin{tabular}{cccccccc}
\hline \multirow{2}{*}{ Extract from } & \multicolumn{8}{c}{ The mass of the sample (in g) } \\
\cline { 2 - 10 } & 0 & 500 & 1000 & 1500 & 25 & 50 & 75 \\
\hline Soil & $97 \mathrm{a}$ & $96 \mathrm{a}$ & $90 \mathrm{~b}$ & $89 \mathrm{~b}$ & - & - & - \\
\hline Roots & $97 \mathrm{a}$ & - & - & - & $82 \mathrm{~b}$ & $80 \mathrm{~b}$ & $37 \mathrm{c}$ \\
\hline Leaves & $97 \mathrm{a}$ & - & - & - & $36 \mathrm{~b}$ & $23 \mathrm{c}$ & $12 \mathrm{~d}$ \\
\hline
\end{tabular}

- The means in lines marked with the same letters do not differ significantly

At the lowest concentration of this extract, there was only a $1 \mathrm{~mm}$ difference in relation to the control. With the increasing of concentrations, the length of leaves was slightly shorter, reaching respectively a value of $90 \mathrm{~mm}$ and $89 \mathrm{~mm}$. The parameters of this feature were worse under the influence of the extracts from roots of Taraxacum officinale; with the increased concentrations of these extracts this value was reduced from $82 \mathrm{~mm}$ to $37 \mathrm{~mm}$. Also Narwall (1994) observed a negative effect of grass root exudates on seedling growth of grasses and other legume plants.

Similarly, as in the case of leaf sheath length, a clear inhibitory effect of the leaf extracts on the tested feature was also observed. Under the influence of the lowest concentrations of the plant extract, there was an average decrease of approximately $63 \%$ in leaf

\section{Table 5}

The length of embryonic roots of Lolium westerwoldicum depending on the concentration of water extracts from soil and plants.

\begin{tabular}{ccccccccc}
\hline \multirow{2}{*}{ Extract from } & \multicolumn{7}{c}{ The mass of the sample (in $\mathrm{g})$} \\
\cline { 2 - 9 } & 0 & 500 & 1000 & 1500 & 25 & 50 & 75 \\
\hline Soil & $56 \mathrm{a}$ & $71 \mathrm{~b}$ & $69 \mathrm{~b}$ & $64 \mathrm{c}$ & - & - & - \\
\hline Roots & $56 \mathrm{a}$ & - & - & - & $33 \mathrm{~b}$ & $29 \mathrm{c}$ & $9 \mathrm{~d}$ \\
\hline Leaves & $56 \mathrm{a}$ & - & - & - & $2 \mathrm{~b}$ & $1 \mathrm{bc}$ & $0 \mathrm{c}$ \\
\hline
\end{tabular}

- The means in lines marked with the same letters do not differ significantly blade length compared to the control, and about $76 \%$ and almost $88 \%$ at higher concentrations.

\section{The length of embryonic roots of Lolium westerwol- dicum}

In this experiment, both the soil and plant (leaves and roots) extracts significantly affected the length of embryonic roots of Lolium westerwoldicum (Tab. 5). The longest roots developed under the influence of the soil extracts. A positive effect of these extracts on the tested feature was noted. In the control treatment, the length of the roots was $56 \mathrm{~mm}$, while in the treatments watered with the soil extract, with the increased concentrations, the value of the studied trait decreased from $71 \mathrm{~mm}$ to $64 \mathrm{~mm}$. 
The inhibitory effect on the length of embryonic roots was observed in the case of application of plant extracts from both roots and leaves of Taraxacum officinale. The results obtained in this study (Tab. 3) indicate a weaker allelopathic effect after the use of the root extracts, where the length of roots was reduced from $33 \mathrm{~mm}$ to $9 \mathrm{~mm}$ with the increased concentrations. But the extracts from leaves showed a very strong allelopathic activity; in this treatment, only the two lower concentrations developed very short roots, and at the highest concentration of this extract, generally embryonic roots were not developed. Similar results were obtained by B reazu et al. (1998) where water extracts of plant residues of Trifolium repens and Medicago sativa and Dactylis glomerata, Festuca pratensis, Festuca rubra, Festuca arundinacea partially or completely inhibited the germination and the growth of roots of Trifolium repens.

The phenomenon of allelopathy occurs in all ecosystems and involves complex chemical communication between them (D u e r, 1996; Li p ińska, 2006; P o t y li c k a and W o j c i k - W o j t k ow i a k, 2001). All the results of the tests conducted in laboratory conditions only indirectly indicate the existence of allelopathic potential of the tested weed species in relation to Lolium westerwoldicum. In field conditions, the potential concentration of allelopathic substances influence mutual interactions resulting from a different botanical composition of agrophytocenoses and a wide range of factors strongly modify the action of organic matter contained in the soil (Wój cik-Woj tkow i a k, 1992). For this reason, the results of laboratory biotests should not be directly transferred to the conditions prevailing in the natural environment, although they indicate the possibility of the studied dependencies. However, one of the important ecological factors affecting the development of different plants is the allelopathy phenomenon, the mechanism of which should be further tested in field conditions.

\section{CONCLUSIONS}

1. Water extracts from both plants and soil in all the concentrations used inhibited the germination energy and germination capacity of Lolium westerwoldicum.

2. It was found that, compared to the soil extracts, the plant extracts exhibited a stronger inhibitory allelopathic effect on the initial growth and development of Lolium westerwoldicum, especially the extracts from the leaves of Taraxacum officinale.

3. The higher concentrations of both plant and soil extracts caused the inhibition of growth of leaf sheaths, leaf blades and roots of the tested plants.

4. In regard to the control treatment, all the concentrations of soil extracts stimulated the extension of embryonic roots of Lolium westerwoldicum.

\section{REFERENCES}

B ert in C., Yang X., We st on L. A., 2003. The role of root exudates and allelochemicals in the rhizosphere. Plant and soil, 256: 67-83.

Beyschlag W., Ryel R. J., U11mann I., Eckstein J., 1996. Experimental studies on the competitive balance between two Central European roadside grasses with different growth forms. 2. Controlled experiments on the influence of soil depth, salinity and allelopathy. Bot. Acta, 109: 449-455.

Bourdot G.W., Woodburn T.L., Briese D. T., Corey S., 1996. Interference between pasture plants and thistles a review. Thistle management workshop, Canberra, Australia, 12 - 13 June 1996. Plant Protection Quarterly, 11, SUP2: 265-270.

Breazu I.T., Boller B., Stadelmann F. J., 1998. Grass/clover mixture merits, allelopathic influence among some grassland species and varieties. Breeding for a multifunctional agriculture. Proc. of the 21st Meeting of the Fodder Crops and Amenity Grasses Section of EUCARPIA, Kartause Ittingen, Swittzerland: 98-99.

Duer I., 1988. Allelopatyczny wpływ niektórych gatunków chwastów na wzrost roślin zbożowych. / The allelopathic impact of some species of weeds on the growth of cereals. Pam. Puł. Prace IUNG, 93: 85-99.

Duer I., 1996. Potencjał allelopatyczny biomasy niektórych gatunków chwastów, w stosunku do siewek pszenicy ozimej (Triticum aestivum var. vulgare). / Allelopathic potential of biomass of some species of weeds in relation to seedlings of winter wheat (Triticum aestivum var. vulgare) Fragm. Agron. (XIII), 2 (50): 6-55

Emeterio L.S., Arroyo A., Casals R. M., 2003. Allelopathic influence of nine grass extracts on germination and seedling growth of afalfa. Agron. Journ. 87: 767772.

Harkot W., Czarnecki Z., Lipińska H., 2000. Allelopatyczne oddziaływanie martwych liści wybranych gatunków traw gazonowych na początkowy rozwój Lolium perenne. Biochemiczne interakcje w oddziaływaniach środowiskowych. / Allelopathic impact of dead leaves of selected species of turf grasses on the initial development of Lolium perenne. Mat. konf. IUNG Pulawy: 57-58.

Harkot W., Lipińska H., Kupczyk J., 1993. Allelopatyczny wpływ wydzielin siewek traw na kiełkowanie nasion Trifolium repens L. i Trifolium pratense L. / Allelopathic impact of grass seedling exudates on the germination of seeds of Triforium repens L. and Triforium pratense L. Fragm. Agron. 4 (40): 221-222.

Harkot W., Lipińska H., 1997. Allelopatyczny wpływ stokłosy bezostnej na kiełkowanie, początkowy wzrost i rozwój niektórych gatunków traw i motylkowatych. /Allelopathic effect of brome grass on germination, initial growth and development of some species of grasses and legumes. Zesz. Post. Nauk Roln. 452: 185-197. 
H offman A., Z a st aw n y J., 2000. Allelopatia a różnorodność florystyczna użytków zielonych. / Allelopathy and floristic biodiversity of grasslands. Aura. 04.

Jodełka J., Jankowski K., Ciepiela G. A., 2003. Wpływ allelopatyczny jastrzębca kosmaczka na początkowy rozwój życicy trwałej i kostrzewy czerwonej. / Allelopathic effects of Hieracium pilosella $\mathrm{L}$. on the initial development of perennial ryegrass and red fescue. Biul. IHAR 225: 353-358.

Leszczyńska D ., Grabiński J., 2004. Kiełkowanie zbóż w układach mieszanych - Aspekt allelopatyczny. [In]: Agrotechnika w kształtowaniu środowiska i jakości żywności:160-165, 60-lecie Wydziału Rolniczego w Lublinie (in Polish).

Lipińska H., Harkot W., 2005. Allelopathic effects of water leachates of Poa pratensis leaves. Allelopathy J. 16: $251-260$.

Lipińska H., 2006. Allelopatyczne oddziaływanie wybranych gatunków traw na kiełkowanie nasion Phleum Pratense w zależności od ich zagęszczenia. / Allelopathic effects of selected grass species on the germination of seeds of Phleum pretense, depending on their density. Acta Bot. 59: 17-28.

Lipińska H., Harkot W., 2007. Allelopatia w zbiorowiskach trawiastych. / Allelopathy in grassland communities. Post. Nauk Roln. 1: 49-61.

Międzynarodowe przepisy oceny nasion. / International Seed Testing Rules. IHAR Radzików, 2002

N arw all S. S., 1994. Allelopathy in crop production. Scientific Publisher, Jodphur, India.

Potylicka B., Wójcik-Wojtkowiak D., 2001. Mechanizmy oddziaływań allelopatycznych. [In:] W. Oleszek, K. Głowniak, B. Leszczyński (eds). Biochemiczne oddziaływania środowiskowe: 13-24. Akademia Medyczna, Lublin (in Polish).

Puntam A. R., Tang Ch. S., 1986. The Science of Allelopathy., Puntam A. R. and Tang C. S., Eds., John Wiley $\&$ Sons, New York.

Souza Filio A. P. S. R., Rodrigues L. R. A., Reis R. A., 1997. Allelopathic interactions among forage grasses and legumes. XVIII Int. Grassld. Congr. Procedings, 2: 61-62.

Takahashi Y., Ontani I., Uozumi S., Yoden Y., Ig a rashi R., 1988. Studies on the allelopathic interactions among some grassland species. I. Effect of root exudates from some grass and legume species on the growth of their own species and other species. J. Japan Soc. Grassl. Sci. 33: 338-344.
Wardle D. A., Nicholson K. S., Rahman A., 1996. Use of a comparative approach to identify allelopathic potential and relationship between allelopathy bioassays and "competition" experiments for ten grassland and plant species. Chemic. Ecol. 22: 933-948.

Wójcik-Wojtkowiak D., 1992. Allelopathic effects in agroecosystems. Acta Acad. Agricult. tech. Olst., Agricult. 55: 11-16.

\section{Allelopatyczny wpływ Taraxacum officinale F.G. Wigg na kiełkowanie nasion i początkowy wzrost Lolium westerwoldicum $\mathrm{R} . \mathrm{Br}$.}

Streszczenie

W runi naturalnych łąk rośliną występującą często w dużych skupiskach jest Taraxacum officinale. Bylina ta szybko rozrasta się, wypierając inne rośliny rosnące $w$ pobliżu. Zatem określenie potencjału allelopatycznego tej rośliny dwuliściennej może zostać wykorzystane w praktyce rolniczej.

Dlatego też celem przeprowadzonych badań było określenie ewentualnego wpływu wyciągów wodnych z liści i korzeni Taraxacum officinale oraz wyciągów glebowych z warstwy korzeniowej tej byliny na kiełkowanie nasion i początkowy wzrost Lolium westerwoldicum. $\mathrm{W}$ wyniku przeprowadzonych badań stwierdzono, że wodne wyciągi zarówno roślinne jak i glebowe we wszystkich zakresach użytych stężeń wpływały hamująco na zdolność i energię kiełkowania nasion Lolium westerwoldicum. W porównaniu do wyciągów glebowych stwierdzono silniejszy hamujący efekt allelopatyczny wyciągów roślinnych, zwłaszcza uzyskanych z liści Taraxacum officinale na początkowy wzrost organów Lolium westerwoldicum. Wyższe użyte stężenia zarówno wyciągów roślinnych, jak i glebowych powodowały hamowanie wzrostu pochewek liściowych, blaszek liściowych i korzeni testowanej rośliny. W odniesieniu do obiektu kontrolnego wszystkie stężenia wyciągów glebowych działały stymulująco na wydłużanie korzeni zarodkowych Lolium westerwoldicum. 